DOI: $10.15290 /$ bsl.2019.14.14

\author{
Aleksandra Białek \\ Wydział Filologii Polskiej i Klasycznej \\ Uniwersytet im. Adama Mickiewicza w Poznaniu \\ e-mail: ab20800@amu.edu.pl \\ ORCID: 0000-0003-2313-3730
}

\title{
Wilk Marka Hłaski, czyli Młoda Polska zakamuflowana (ukryte nawiązania do prozy Żeromskiego i Reymonta)*
}

Odkrycie dokonane w roku 2013 i upublicznione w roku 2015 przez Radosława Młynarczyka - studenta gdańskiej polonistyki, uczestnika seminarium prof. Stefana Chwina - wywołało niemałe poruszenie wśród literaturoznawców. Nikt bodaj nie spodziewał się, że napisana ponad 60 lat temu, młodzieńcza, poprzedzająca Sonatę marymoncka powieść Marka Hłaski zostanie przypadkiem zidentyfikowana w archiwum Zakładu Narodowego im. Ossolińskich ${ }^{1}$. Ta wydana pod tytułem Wilk historia dojrzewania chłopaka z przedwojennego Marymontu - jednej z najbiedniejszych wówczas dzielnic Warszawy - stanowi ewenement w pisarskim dorobku Hłaski z co najmniej kilku powodów.

Po pierwsze, w Wilku w sposób nieskrępowany dochodzi do głosu wrażliwość autora, zauważana $w$ innych utworach przez niektórych badaczy, jak na przykład przez Stanisława Stabrę wprost stwierdzającego, że: „Hłasko

\footnotetext{
* Większość tez tego artykułu została przeze mnie zaprezentowana i szerzej udokumentowana w pracy magisterskiej: Harmonia złodziejska. Muzyczność "Wilka" i innych wczesnych utworów Marka Hłaski wobec prozy Stefana Żeromskiego i Władysława Reymonta, napisanej pod kierunkiem prof. dra hab. Radosława Okulicz-Kozaryna.

${ }^{1}$ Odwołuję się tutaj do wypowiedzi R. Młynarczyka udzielonej w wywiadzie dla stacji telewizyjnej TVN24. Odkrył nieznana powieść Marka Hłaski. „Niezwykły łut szczęścia”, „TVN24.pl”, https://www.tvn24.pl/xiegarnia,66,m/xiegarnia-w-tvn24,602226.html, [dostęp 12.04.2018].
} 
to [...] wrażliwy uczuciowiec" ${ }^{2}$. Po drugie, powieść ta stanowi niezwykły splot techniki naturalistycznej z lirycznym obrazowaniem, przy czym dominującą rolę zdaje się odgrywać liryzm. Po trzecie, młodzieńcze dzieło Hłaski jest silnie nasycone pierwiastkiem muzycznym. Muzyka objawia się na wszystkich trzech poziomach, jakie wyróżnia zarówno Ewa Wiegandt, czyli: muzyki literatury, muzyki w literaturze oraz muzyczności literatury ${ }^{3}$, jak i Andrzej Hejmej, a zatem: muzyczności I, muzyczności II oraz muzyczności III ${ }^{4}$. Wilk i Sonata marymoncka, ze swym tytułem o muzycznej proweniencji, tworzą - według określenia Młynarczyka - „palimpsest absolutny".

Wrażliwość, liryzm, muzyczność - charakteryzujące pierwszą powieść Hłaski - każą rozpatrzyć możliwe związki tej powieści z prozą Młodej Polski, jako że wówczas właśnie te cechy znalazły najsilniejszy wyraz w literaturze. W istocie, zestawiając Wilka z utworami z przełomu XIX i XX wieku, zwłaszcza Stefana Żeromskiego i Władysława Reymonta, znaleźć można u Hłaski wiele zakamuflowanych odwołań do prozy tych autorów i aktualizacji wykorzystywanych przez nich technik pisarskich.

\section{Hłasko i Żeromski}

\subsection{Brudne ulice i jasne domy}

Wiernym czytelnikom „polskiego Jamesa Deana” - jak zwykło się określać Hłaskę - zapewne znany jest cytat zawarty w Pięknych dwudziestoletnich:

Moja matka, która kazała mi czytać, wepchnęła mi kiedyś Żeromskiego; miałem wtedy dziesięć lat. Przeczytałem zdanie: „Śnica zapuścił sępie spojrzenie swoich źrenic w jej duszę". Poczułem się zwolniony na zawsze z obowiązku czytania Żeromskiego; $[\ldots]^{5}$.

Hłasko - co można zauważyć bez trudu - zaprzecza w ten sposób inspiracji pisarstwem Żeromskiego. Należy jednak pamiętać, że dzieło, z jakiego pochodzi cytowany fragment, to quasi-autobiografia, w której fakty mieszają się z fikcją, a narratorowi - choć posiadającemu pozory prawdziwości - nie

\footnotetext{
2 S. Stabro, Legenda i twórczość Marka Hłaski, Wrocław 1985, s. 53. Wrocław 1980.

4 A. Hejmej, Muzyczność dzieła literackiego, Wrocław 2001.

5 M. Hłasko, Piękni dwudziestoletni, Warszawa 1989, s. 21.
}

3 E. Wiegandt, Problem tzw. muzyczności prozy powieściowej XX w., w: Pogranicza i korespondencje sztuk. $Z$ dziejów form artystycznych w literaturze polskiej, red. T. Cieślikowska, J. Sławiński, 
można wierzyć na tak zwane „słowo”. Mimo że pisarz, nazywany przez badaczy „młodym gniewnym”, demonstracyjnie odżegnuje się od młodopolskiej tradycji literackiej, jest mu ona - co warto podkreślić - dobrze znana, zwłaszcza dzięki pośrednictwu matki, Marii Hłasko, która studiowała filologię polską. Jego oczytanie, w tym także oczytanie w literaturze przełomu wieków XIX i XX, zauważyli między innymi Jerzy Jarzębski i Joanna Pyszny, nie widząc w tym zresztą niczego wyjątkowego. $\mathrm{W}$ „obowiązkowych lekturach każdego młodego [ówcześnie] Polaka” obok „wielkich romantyków i pozytywistów" ważną rolę odgrywała również twórczość autorów młodopolskich, szczególnie Wyspiańskiego i Żeromskiego ${ }^{6}$. Nawiązanie do znanego utworu drugiego $\mathrm{z}$ nich widać choćby $\mathrm{w}$ takim oto fragmencie Wilka:

na ulicy Kamedułów, gdzie jedną stroną ulicy waliły się rudery, a drugą płynęła mętna łacha, wyciągał się w niebo czerwony komin Warszawskiej Fabryki Wyrobów Blaszanych Bielany [...].

Przy tych ulicach krzywych i prostych, [...] prowadzących od jednej bidy do drugiej, w tym całym pokurczonym labiryncie głodu stały domki i domy rozmaite. Domy chwackie i bogackie, murowane [...], i drewniane, krzywe chału piny stojące $\mathrm{z}$ boku: zastrachane i jakby zawstydzone takim sąsiedztwem, a na ostatku jeszcze ni to domy, ni to budy, sklecone byle jak i nie wiadomo z czego, połatane blachą i skrawkami papy znalezionej na budowie [...], najeżone nieprzyjaźnie zardzewiałymi rurami od piecyków ${ }^{7}$.

Opis obrzeży Warszawy przypomina w swoim klimacie dobrze znany fragment Ludzi bezdomnych:

szedł ulicami w stronę przedmieścia ze zwieszoną głową, machinalnie szukając oczyma fabryki cygar. Nie było tam już jednolitego szeregu kamienic i rzadziej trafiały się domy piętrowe. Natomiast szły w dal drewniane, niskie, odrapane budynki, niepodobne ani do dworów, ani do chałup wiejskich, a przypominające jedne i drugie. [...]

Gdzieniegdzie ze środka tych zagród miejskich, okrytych starą ceglaną dachówką albo papą, na której rozkłada się już tu i ówdzie pleśń zielona, strzelała w górę nowa kamieniczka, szybko postawiona, jakby wydmuchnięta z piasku. [...] Jeszcze częściej połać domów niskich przerywał ogromny tors fabryki z tęgimi murami, szeroką bramą i baterią kominów. W dali na horyzoncie dachów ukazywały się wszędzie te kominy i kominy ${ }^{8}$.

\footnotetext{
6 Zob. J. Pyszny, Wstęp, w: M. Hłasko, Pierwszy krok w chmurach, Następny do raju, Wrocław 1999, s. XLII.

7 M. Hłasko, Wilk. Wydanie krytyczne, Warszawa 2015, s. 5. Wyróżnienia w tym i innych cytatach pochodzą od autorki artykułu.

8 S. Żeromski, Ludzie bezdomni, w: Pisma zebrane, t. 8, red. Z. Goliński, oprac. W. Wasilewska, Warszawa 1997, s. 42-43.
} 
Przedmieścia stolicy $\mathrm{w}$ opisach dokonanych zarówno przez jednego, jak i drugiego autora ukazują rozpad świata i rozkład wartości. Peryferyjne ulice Warszawy stanowią eklektyczny zlepek krzywych, lichych domów, dachów połatanych blachą bądź skrawkami papy oraz fabrycznych kominów. Nad całym tym kolażem rachitycznych elementów unosi się atmosfera choroby i głodowej śmierci. "Najeżone nieprzyjaźnie budy” u Hłaski i "tors fabryki" u Żeromskiego wskazują na związki ich pisarstwa z techniką naturalistyczną, polegającą $\mathrm{w}$ tym wypadku na nadawaniu przedmiotom cech organizmów żywych. Poza naturalizmem - o którym w odniesieniu do Hłaski wiele już napisano - w powieści o warszawskim Marymoncie występuje nader ważny, nawiązujący wprost do prozy autora Przedwiośnia motyw. Odnaleźć go można między innymi $w$ takim oto fragmencie:

Zza Żoliborza wychynęła nagle na niebo różowa poświata, rozkrwawiła delikatnie niebieskość. [...] Dzień wiosenny zaczynał budzić się ptakami, szumieć, słońce [...] zagrało tysiącami kolorów. Rączyn położył dłoń na ramieniu Ryśka. A okna jasnych domów rozbłysły nagle tęczowo, diamentowo - wiosennego słońca kolorem [...]. I nagle $\mathrm{z}$ blasków słońca, $\mathrm{z}$ kropel rosy wirujących tęczowo w powietrzu, z całej krasy rodzącego się dnia wyszczerzyły się wysokie Cygańskie Budy, zgrzytnęły, uderzyły boleśnie o oczy walącą się nędzą. To było tak nagłe, że obaj drgnęli, przestraszeni jakby ${ }^{9}$.

"Jasne domy" pośrednio odnoszą się do "szklanych domów", przedstawionych tu na zasadzie podobnego rozczarowania światem, jakie towarzyszyło Cezaremu Baryce, który:

patrzał posępnymi oczyma na grząskie uliczki, pełne niezagruntowanego bajora, na domy rozmaitej wysokości, formy, maści i stopnia zapaprania zewnętrznego, na chlewy i kałuże, na zabudowania i spalone rumowiska. [...]

„Gdzież są twoje szklane domy? - rozmyślał brnąc dalej. - Gdzież są twoje szklane domy?..." ${ }^{10}$.

To nawiązanie i twórcze przekształcenie motywu ukazuje zainteresowanie Hłaski pisarstwem Żeromskiego. Zastanawiającą kwestią jest to, dlaczego Młynarczyk w swoim Wstępie krytycznym, w rozdziale Utwory przeczytane przez Hłaskę nie wyróżnia Przedwiośnia, stanowiącego w tym wypadku jeden z głównych punktów odniesienia artystycznego i ideowego. "Jasne domy" Hłaski i "szklane domy” Żeromskiego pełnią podobną funkcję - symbolu

9 M. Hłasko, Wilk, s. 122-123.

10 S. Żeromski, Przedwiośnie, Wrocław 1982, s. 107. 
niespełnionych marzeń o lepszym życiu. Ich idealne wyobrażenie kontrastuje z szarą codziennością, której niezmiernie daleko do doskonałości. W Wilku kontrast ten zostaje dobitnie ukazany przez ulokowanie miejsca akcji poszczególnych fragmentów powieści na styku Marymontu - dzielnicy "Cygańskich Bud" i Żoliborza - dzielnicy pięknych, "jasnych domów"11, stanowiących dla Ryśka (przyzwyczajonego do widoku koślawych lepianek) nieosiągalny ideał. Nie bez znaczenia jest także czas akcji utworu, przypadający na moment, w którym żoliboskie osiedle realnie wzbogaciło się o nowo powstałe budynki, stanowiące realizację idei spółdzielczych, którym patronował Żeromski. Co bowiem nader istotne - $\mathrm{w}$ budowę Żoliborza zaangażowane było Stowarzyszenie "Szklane Domy". Hłasko świadomie przetworzył więc rzeczywiste zdarzenia zręcznie włączając je do powieści, bowiem to właśnie o tych nowoczesnych domach marzy główny bohater. Jednak nie tylko naturalistyczne opisy podmiejskiej przestrzeni, historie ludzi ze społecznego marginesu czy analogiczne motywy decydują o związkach Wilka z prozą młodopolskiego twórcy. Jak bowiem zauważa Młynarczyk, powieść tę

przyporządkować do naturalizmu można tylko pod pewnymi względami. Wszystkie drastyczne sceny i motywy w powieści [...] opisane są w sposób niemal reportażowy, opatrzony jednak nieśmiałym śladem symbolizmu ${ }^{12}$.

Z pierwszą częścią tego twierdzenia należy - jak już dowiodłam - się zgodzić, na drugą, którą dopiero przedstawię - również trzeba będzie przystać, z tym zastrzeżeniem, że ślady wcale nie są nieśmiałe. Wywodzą się one wprost z poetyki młodopolskiej.

\subsection{Liryzm języka i melodia świata}

W Wilku pierwiastki liryczne pojawiają się w tak dużym natężeniu, że nie sposób ich wszystkich przywołać. Warto jednak zwrócić uwagę na pewne określenia językowe, typowe dla nastrojowości młodopolskiej, a wykorzystywane też przez Hłaskę. Należy do nich często pojawiający się motyw „perlistej trawy”, widoczny na przykład w takim fragmencie: „Trzeba było czekać, jak księżyc zapadnie w ciemną chmurkę [...]. Położył się w sprężystej, sperlonej trawie i czekał cierpliwie"13. By jednak w pełni ukazać wpływ

\footnotetext{
11 Słowo ,jasny" kojarzyć się może także z ,jjasnym jutrem" - hasłem (jak powszechnie wiadomo) rozpropagowanym w okresie PRL-u. Hłasko bazuje więc na jeszcze innych kontrastach, przeciwstawia sobie m.in. kapitalizm i komunizm.

12 R. Młynarczyk, Wstęp, w: M. Hłasko, Wilk, s. XXXIII.

13 M. Hłasko, Wilk, s. 111.
} 
Młodej Polski na wrażliwość i warsztat pisarski dziewiętnastoletniego wówczas autora, przywołam cytat prezentujący iście młodopolską poetyckość języka i obrazowość opisu:

Rosa wieczorna osiadła na trawie chłodziła przyjemnie [...]. Wieczór w nockę przechodził niepostrzeżenie, gwiazdy zerkały z wysoka, a od Wisły nawiewał rześki, pachnący wodorostami wiaterek. [...] księżyc srebrzył się łuskowato, przepluskiwał drobniuteńkimi falami w wodzie wyjaśnionej i czystej, przy brzegach chwiały się ukośne cienie wiklin, a w zaroślach na drugim brzegu popłakiwały cienko i trzepotały skrzydłami nocne ptaki. Rysiek stał chwilę urzeczony olejnością tego obrazu i ciszą osiadłą wokół: mroczną, głęboką, aż szumiącą ${ }^{14}$.

Podobny nadwiślański pejzaż, choć przedstawiony o innej porze dnia - nie o zmierzchu, lecz o świcie - odnaleźć można również w Ludziach bezdomnych:

Ulice pełne już były światła słonecznego. Przy domach otulonych drzewami słały się fiołkowe, pachnące cienie.

Tomasz i Wiktor zawrócili właśnie w kierunku dzielnicy fabrycznej i stanęli na wzgórzu, skąd ją całą można było widzieć. Z głębi odległych murów ciągnęła w szczere pole Wisła, wygięta jak ogromny łuk z jasnego srebra. Zdawało się, że płonie białym blaskiem, zapalona przez słońce poranne. Spragnione oko chwytało daleki widok tej swobodnej wody, zielonej równiny łąk, sinych lasów, nikłymi liniami ginących w przestworzu. Bliżej nad Wisłą ciemniały kępy jakiś drzew rozłożystych ${ }^{15}$.

W zestawionych fragmentach wyróżnić trzeba malarskie obrazowanie z właściwym mu srebrzysto-świetlistym kolorytem, motyw mroku czy raczej półmroku i towarzyszącą mu grę cieni. Tym, co jeszcze mocniej niż malarskość zespala ze sobą styl obu autorów, jest muzyczność - dźwięki współtworzące harmonię świata. Zaznaczyć należy, że skala różnorodnych głosów i odgłosów jest tak szeroka, że w jej obręb wchodzą nie tylko miłe dla ucha delikatne tony, lecz także brzmienia dysonansowe. Tak dźwięki przenikające elementy otaczającej przestrzeni ukazuje Hłasko:

na Blaszance światła były mocne, biły na ulicę jasnymi, pewnymi snopami, razem z jękiem i postukiwaniem maszyn. Nocami wyły rozpaczliwie bezpańskie psy, [...] a Zieliński młodszy rozdeptywał wszerz, wzdłuż i zygzakiem błotną ulicę, także śpiewał. [...] I głos ten tłukł się bezpańsko po opłotkach [...] ${ }^{16}$.

\footnotetext{
14 Tamże, s. 109-110.

15 S. Żeromski, Ludzie bezdomni, s. 56.

16 M. Hłasko, Wilk, s. 58-59.
} 
Tak zaś Żeromski:

Z niziny fabrycznej, [...] z wąskich i podłużnych budowli, które cienkimi rurami wydychały kłęby pary, przecudne $w$ promieniach słońca, [...] dochodził nie milknący łoskot żelaza. Doktór Tomasz ulegał złudzeniu, że te dźwięczne uderzenia młotów, owe jęki jak gdyby targanych łańcuchów wydaje para buchająca na wsze strony z dachów okrytych zadymioną papą. [...] Po rozbitym bruku ulicy toczyły się wozy ciągnione przez ogromne koniska. [...]. Niektóre $\mathrm{z}$ nich słychać było $\mathrm{w}$ sąsiedniej ulicy ${ }^{17}$.

Właśnie muzyczność będzie jednym z najbardziej zakamuflowanych i zarazem istotnych łączników między prozą Hłaski a prozą Młodej Polski. Melodia i motyw harmonii - rozumianej zarówno jako instrument, jak i kategoria filozoficzno-estetyczna, odgrywają w Wilku ważną rolę, o czym świadczy na przykład następujący cytat:

Harmonia złodziejaszka Zielińskiego, ten instrument, w którym musiała pokutować jakaś dusza zaczarowana i nieszczęśliwa, wywabiała ludzi z walących się domków, [...] spraszała na jedną chwilkę zapomnienia, tęczą kolorową tłukła się w opłotkach, wyczarowywała nutkę szczęścia nieprawdopodobnego, bolesnego jakiegoś $\mathrm{w}$ tej szarzyźnie. [...]

Była w tych mrocznych śpiewkach i rozpacz, i ból, czasem pragnienie czegoś lepszego $[\ldots]^{18}$.

Istotną rolę muzycznych inspiracji dostrzec można także tutaj:

ulicą nadtoczył się [...] Zielińszczak młodszy. Kołysała się z nim ulica, a pan Zdzisio zawołał:

Szesnaście lat, więzienia się nie boję,

Szesnaście lat, to fraszka dla mnie jest!

Szesnaście lat więzienia ja odstoję,

Chociaż zabiłem dwoje, odstoje, bo zdradziła mnieeeеee...

Skakał wariacko po opłotkach rozchybotany jego cień. Złodziejaszek płynął jak gondola, rozśpiewany wiosennie ${ }^{19}$.

Można nawet pokusić się o stwierdzenie, że cała powieść skomponowana została $\mathrm{z}$ ballad, tych przywoływanych explicite $\mathrm{w}$ wypowiedziach bohaterów i tych zawartych immamentnie w opisie przestrzeni. Współtworzą one jedną wielką balladę o losach międzywojennego Marymontu. Muzyczność

\footnotetext{
17 S. Żeromski, Ludzie bezdomni, s. 56-57.

18 M. Hłasko, Wilk, s. 22-23.

19 Tamże, s. 145.
} 
łączy także pisarstwo Hłaski z twórczością innego pisarza Młodej Polski, a mianowicie - Władysława Reymonta.

\section{Hłasko i Reymont}

\subsection{Harmonia złodziejska i muzyczny nastrój}

Zaznaczyć należy, że muzyka, jaką wykorzystuje Hłasko, nie jest muzyką rejestru wysokiego, elitarnego, lecz niskiego, ludycznego. Inspiracji nie stanowią tu kompozycje fortepianowych mistrzów, ale podwórkowe przyśpiewki lokalnych grajków. Podobna sytuacja ma miejsce $\mathrm{w}$ tych nowelach Reymonta, w których odnaleźć można całą gamę najróżniejszych melodii objawiających się na wszystkich trzech poziomach, wyróżnionych przez Hejmeja i Wiegandt. Zarówno więc w pisarstwie Hłaski, jak i autora Chłopów pojawia się suondscape, czyli tzw. krajobraz dźwiękowy ${ }^{20}$ oraz oryginalne przetworzenie ludowych bądź miejskich utworów. Cytaty z przyśpiewek, połączone z opisem głosów słyszalnych w przestrzeni, rozbrzmiewają na przykład w noweli Reymonta z roku 1895, o krótkim tytule - Przy robocie ${ }^{21}$ :

- Chamy, a ruszać się tam!

I jakby w odpowiedzi, po drugiej stronie zerwał się śpiew chóralny i rozpływał wolno, szarpany przez wiatr.

Jedna baba z Pocieja!...

Z Pocieja...

Pokochała złodzieja -

Złodzieja!

20 Nazywany również „pejzażem dźwiękowym”, to koncepcja stworzona w roku 1967 przez Raymonda Murraya Schafera, pisał on o niej np. w swojej słynnej pracy Muzyka środowiska. Badacze dowodzą, że sam termin jest jednak wcześniejszy i po raz pierwszy pojawił się w roku 1965 w książce innego kompozytora - Alvina Luciera. Zob. R. Tańczuk, „Pejzaż dźwiękowy" jako kategoria badań nad doświadczeniem miasta, "Audiosfera. Koncepcje - Badania Praktyki" 2015, nr 1, s. 12.

21 Pierwodruk noweli ukazał się w "Głosie" (w numerach 11 i 12), następnie utwór ten wszedł w skład zbioru $W$ jesienna noc wydanego w roku 1900. Inną małą formą prozatorską Reymonta, w której muzyka odgrywa podobną rolę do tej, jaką nada jej później Hłasko, jest np. nowela Na bruku. Odczucia, jakich pod wpływem melodii doznaje jej bohater, przywodzą na myśl te, którym ulegają mieszkańcy Marymontu w Wilku. Dowodzi tego chociażby następujący cytat z noweli, który podkreśla dodatkowo wagę występującego w obu dziełach motywu harmonii: „Ta śpiewka, [...] która rytmem swoim przynosi mu ból i rozkosz przypomnień [...] - kiedy światło gwiazd, ciepło, wonie [...], przepełniały mu serce i mózg niezmierną harmonią" [W. Reymont, Na bruku, w: tegoż, Nowele, t. 1, red. Z. Skrzatówna, Kraków 1956, s. 79-80]. 
Odpowiadano $\mathrm{z}$ tej strony rzeki i śpiew się ciągnął nieprzerwanie, przeplatany tylko hukiem bab bijących i głosem komend i brzmiał coraz wolniej, smutniej i ciszej, to przerywał się $w$ jakimś chrapliwym akordzie i baby wtedy huczały głośniej, i zgrzyt pomp przecinał ze świstem powietrze ${ }^{22}$.

Pojawiające się $\mathrm{w}$ tym fragmencie dźwięki przestrzeni wydawane przez narzędzia pracy: „baby” czy „pompy”, przywodzą na myśl przywoływane już tutaj wyimki z Wilka i Ludzi bezdomnych, co jeszcze wyraźniej dowodzi, jak bardzo zainspirował się Hłasko młodopolskimi technikami pisarskimi. Autor Sonaty marymonckiej - podobnie do Reymonta - podwyższa rangę melodii nie tylko przez umuzykalnienie elementów świata przedstawionego, lecz także dzięki przywołaniu szlagierów. Oto przykład z Wilka:

I zaśpiewał. Tak jak Zieliński: rozciągliwie, z przeciągnięciem ochrypłym na ostatniej literze, żeby aż w sercu drapało:

Dla niej bandyta bytem,

Dla niej życieeee zgubiteeem,

Przez niq w więzieniuu gniłem,

Przez nia pięć osób siekiera zabiteeeeeem! ${ }^{23}$

Specyfikę tego rodzaju muzycznych inklinacji trafnie objaśniał Leopold Tyrmand, pisząc w książce $U$ brzegów jazzu:

Teoretycy współczesnej kultury wyrażają się o [miejskiej balladzie] często z przekąsem i kamuflowaną ironią, nazywając ją sztuką podwórzową, sztuką ulicy albo plebejską sztuką niepohamowanego rozwoju urbanizmu, w łonie którego życie ulicy i podwórza staje się, nie zawsze w sposób od razu dostrzegalny, ważkim elementem kultury codzienności, a z czasem i kultury artystycznej. Najtypowszy jej produkt: ballada miejska zaczyna od początków wieku drążyć bez wytchnienia i z doskonałym skutkiem całą niemal sztukę współczesną $[\ldots]^{24}$.

Kariera piosenek podwórkowych związana była niewątpliwie z „niepohamowanym rozwojem urbanizmu", co jako jeden z pierwszych zauważył właśnie Reymont w przytoczonej noweli. Przyśpiewkę Miała baba koguta przekształca on tam w swego rodzaju miejską balladę o babie zakochanej w złodzieju. Autor Ziemi obiecanej dopisuje ją tym samym do szeregu pieśni o przestępczym środowisku dużych miast. Można więc syntetycznie stwierdzić, że to,

\footnotetext{
${ }^{22}$ W. Reymont, Przy robocie, w: tegoż, Nowele, t. 1, s. 228-229.

23 M. Hłasko, Wilk, s. 73.

${ }^{24}$ L. Tyrmand, U brzegów jazzu, Warszawa 2014, s. 83-84.
} 
co zapoczątkował Reymont, zgodnie z duchem nowej epoki, choć wciąż pamiętając o poprzedniej, kontynuował będzie Hłasko.

Szczególnie interesujący, zarówno w kontekście powieści Hłaski, jak i noweli Reymonta, wydaje się być również następujący cytat:

Okres rozkwitu warszawskiego folkloru miejskiego to schyłek XIX wieku i lata aż do I wojny światowej. Pojawiają się wtedy coraz to nowe ballady rynsztokowe o tematyce lumpenproletariackiej i przestępczej, znajdujące - co ważne - całe zastępy anonimowych kolporterów i interpretatorów o pełnym poczuciu stylu i częstokroć nie byle jakim talencie, produkujących się nieustannie na weselach, chrzcinach, imieninach, w czasie zielonoświątkowych majówek na Bielanach i w Młocinach, w podmiejskich salach tańca, na odpustach i kiermaszach - przy każdej publicznej okazji. Nurt brukowych klechd o Czarnej Mańce, pannie Wiśniewskiej, o sławnych bandytach i o nie mniej sławnych ofiarach wielkich namiętności erotycznych splatał się natenczas harmonijnie z nurtem ogródkowo-walczykowych rozrywek, $[\ldots]^{25}$.

Moment opisanych w tym fragmencie przemian zachodzących w miejskim folklorze przypada na czas pisarskiej działalności Reymonta, jednak w pełni z inspiracji tych skorzysta później Hłasko nie tylko poprzez częste odwołania do ballad o Czarnej Mańce, lecz także opisy muzycznych popisów wykonywanych podczas festynów czy rodzinnych świąt (na przykład chrzcin). Ważne w kontekście Wilka okażą się również przywołane w tym cytacie Bielany i Młociny. To właśnie wybór podobnej przestrzeni, zwłaszcza rejonów podmiejskich i skupienie na tragicznych historiach ich mieszkańców, stanowią kolejną wspólną płaszczyznę, po której poruszają się obaj autorzy.

\subsection{Ludzie marginesu i cywilizacyjne przemiany}

Między wybranymi utworami Hłaski i Reymonta poza podobieństwami stylu oraz ujęcia i roli muzyki, występują jeszcze inne powiązania. Należy do nich na przykład obraz zbiorowości społecznych marginesów, a także bohaterów stających w obliczu szybkich i nagłych zmian związanych z rozwojem cywilizacji. Problem urbanizacji i industrializacji, kurczenia się wsi i rozrastania miast oraz towarzyszących temu nastrojów, stanie się ważnym punktem zespalającym problematykę zestawianych tu dzieł obu pisarzy. Zbliżać będzie ich także paralelne spojrzenie na zachowania i stan ludzi zamieszkujących zarówno peryferia, jak i ulokowanych w centrum. Wspólny im obu okaże się szczególnie sposób przedstawienia biedoty prowincjonalnej - jak określiła ją

\footnotetext{
25 Tamże, s. 90.
} 
Mirosława Puchalska - „bardzo zróżnicowanej wewnętrznie, ale i zrównanej nędzą i wyzyskiem [...]"26. Zarówno w Wilku, jak i w wybranych, małych formach epickich Reymonta wyraźnie da się zauważyć cierpienie bohaterów spowodowane złymi warunkami życiowymi i ciężką pracą.

Warto podkreślić, że inspiracje, jakie obaj twórcy czerpali z doświadczeń ludzi żyjących na marginesie, biorą się nie tylko z rozbudowanych zmysłów obserwacji i pisarskiego talentu, lecz także własnych realnych przeżyć. Zarówno Reymont, jak i Hłasko w pewnych okresach swego życia obracali się w kręgach różnych ubogich warstw. Tak jedno ze swoich najtrudniejszych, dość wczesnych doświadczeń wspomina autor Na bruku w biograficznym liście z 15 kwietnia 1903 roku, skierowanym do pisarza i tłumacza - Antoniego Wodzińskiego: „Tych pierwszych lat literackich nie będę opisywał, są fatalne przez nędzę swoją, przez najgorszą z nędz, bo cierpianą na miejskim bruku, ale jakoś się przeżyło i przecierpiało" 27 . Do tych właśnie „pierwszych lat literackich" zaliczają się przywołane w tym artykule nowele, w których jak dowodzi tego cytowany fragment listu - pobrzmiewają echa osobistych przykrości i trudów. Tak z kolei, doświadczenie ciężkiej pracy pośród niedocenionych ludzi opisuje Hłasko w - pełnych mitów, ale i faktów - Pięknych dwudziestoletnich:

Pytano mnie wielokrotnie, czy rzeczywiście było tam tak, jak o tym napisałem. Nie, nie było tak. Było o wiele gorzej: wstawaliśmy rano o czwartej, a o dziesiątej wieczór kończyliśmy rozładunek [...]. Niedziel i świąt nie było; pod koniec miesiąca kierownik bazy w Bystrzycy Kłodzkiej oświadczał nam, że wyrobiliśmy około czterdziestu, czasami około czterdziestu pięciu procent normy. [...] $\mathrm{W}$ tym czasie widziałem dwa wypadki śmiertelne i jeden wypadek złamania kręgosłupa $[\ldots]^{28}$.

Krótka relacja dotycząca wypadków kojarzyć się może z tragiczną śmiercią bohatera noweli Przy robocie - Grzeli, jednego z chłopów-robotników pracujących na budowie i dowodzić, że w kwestii bezpieczeństwa podczas wykonywania fizycznych prac mało się zmieniło. Warto w tym miejscu zaznaczyć, że jeśliby nawet uznać quasi-autobiografię Hłaski za całkowitą fikcję literacką, to twórca ten przystępując do pisania Wilka - podkreślmy raz jeszcze: swojej wczesnej, młodzieńczej powieści - czyli w okolicy roku 1952, miał za sobą liczne, trudne, udokumentowane przez badaczy przeżycia. Już bowiem dwa

\footnotetext{
26 M. Puchalska, Wokół Młodej Polski. Szkice i sylwetki, Warszawa 2008, s. 15.

27 W. Reymont, Korespondencja 1890-1925, oprac. B. Koc, Warszawa 2002, s. 733.

28 M. Hłasko, Piękni dwudziestoletni, s. 12.
} 
lata wcześniej (niedługo po ukończeniu 16 roku życia), przyszły prozaik podjął pracę między innymi w Stoczni Rzecznej we Wrocławiu, następnie w Centrali Rybnej, Ekspozyturze we Wrocławiu, a pod koniec roku w Państwowej Centrali Drzewnej PAGED we wspomnianej bazie w Bystrzycy Kłodzkiej29, w której pobyt określać będzie jako jedno ze swoich najcięższych przeżyć. Podobnie więc jak w wypadku młodego Reymonta, kariera pisarska autora Następnego do raju poprzedzona została tułaczką, nędzą, obcowaniem z przedstawicielami marginalizowanych środowisk i wykonywaniem różnych, często nierentownych lub słabo opłacanych prac. Należy zatem stwierdzić, że w jakiejś mierze przedstawione tu powody złożyły się na fakt, iż obaj pisarze wiele miejsca poświęcili tematyce związanej z niedolą biednych, zmęczonych i wynędzniałych ludzi. Wnioski te, choć zakrawają o truizm, rzucają jednak pewne światło na tak ważny dla Hłaski splot życia i pisania.

Mimo licznych podobieństw pamiętać także należy o znaczących różnicach dzielących pisarstwo Hłaski od literatury Żeromskiego i Reymonta, wynikających chociażby z dużego odstępu czasowego między epokami, w których przyszło im tworzyć, choć w ujęciu niektórych badaczy powiązania autora Sonaty marymonckiej z młodopolskimi twórcami mogłyby się wpisywać w szerzej rozumianą formację modernistyczną, o której pisał między innymi Ryszard Nycz. Autor Języka modernizmu za modernistyczne uznał bowiem utwory, które powstawały od końca XIX stulecia do (mniej więcej) lat 60. $X X$ wieku $^{30}$. Na takie rozumienie modernizmu nie zgadzają się jednak poszczególni historycy literatury, a dyskusja dotycząca periodyzacji epok jest - jak powszechnie wiadomo -wciąż otwarta ${ }^{31}$. Na uwagę $w$ tej kwestii za-

29 Zob. P. Wasilewski, Śladami Marka Hłaski, Kraków 1994, s. 12.

30 Modernistyczna formacja literacka, jak definiuje ją Nycz, to konstelacja „stanowisk literackich i pochodnie światopoglądowych, które kształtowały się (konsekwentnie i nieprzerwanie) od lat dziewięćdziesiątych XIX wieku, osiągnęły swą krystalizację około roku 1910, a miały przed sobą długą jeszcze przyszłość" [R. Nycz, Język modernizmu. Prolegomena historycznoliterackie, Wrocław 1997, s. 15]. Wątpliwość wzbudza podkreślenie roli, jaką odegrać miały lata ok. 1910 roku, co łączyć się może z innym, dyskusyjnym fragmentem, w którym Nycz stwierdza, iż panuje dość powszechna zgoda, że najwartościowsze zjawiska w literaturze Młodej Polski pojawiły się w latach 1902/3-1912/13 [tamże, s. 9]. Stanowiska badaczy na temat najcenniejszych dzieł i najistotniejszych zjawisk opisywanego okresu nie są jednak w pełni uzgodnione, wielu odbiorców tej literatury coraz częściej rewiduje swoje spojrzenie na „młodopolszczyznę" i dostrzega jej ogromną wartość już w latach 90. XIX w. (zwłaszcza w symbolicznym roku 1894).

31 Intrygująco o modernizmie pisał na przykład Włodzimierz Bolecki w swoim artykule Modernizm w literaturze polskiej XX wieku (rekonesans), w którym dokonuje m.in. rozróżnienia na modernizm "szerszy” i „węższy” oraz wyróżnia (zaczynając od połowy XIX wieku) najważniejsze zjawiska, które składają się na współczesne rozumienie modernizmu, takie jak np.: oświeceniowo-romantyczna koncepcja „rewolucji estetycznej”; koncepcja modernite - sztuki przedsta- 
sługuje choćby recenzja rewolucyjnej rozprawy Nycza autorstwa Tomasza Lewandowskiego. Zdaniem poznańskiego badacza, postulowane w Języku modernizmu spojrzenie na literaturę:

oznacza, że dziejom literatury polskiej XX wieku zapewniają ciągłość jedynie pisarze nowatorzy, mistrzowie intelektualnych i literacko-artystycznych inwencji o rożnych rodowodach, od młodopolskiego poczynając, oraz ich następcy po roku 1960, swobodnie przekraczający granice uprzednio wyznaczonych opozycji. Zgodnie z taką przesłanką aksjologiczną oś konstrukcyjną projektowanej wstępnie narracji historycznoliterackiej stanowiłby prosty układ dychotomiczny: modernizm - postmodernizm, prowadzący do redukcji, a właściwie do eliminacji z pola widzenia badacza literatury XX-wiecznej wszelkich tendencji i nurtów literacko-artystycznych krystalizujących się, najogólniej mówiąc, poza nim, niezależnie, a np. różnorako powiązanych z tradycjami realizmu klasycznego ${ }^{32}$.

Rozważania Nycza budzą jednak więcej zastrzeżeń, rodząc przy tym liczne pytania, które śmiało formułuje Lewandowski ${ }^{33}$ :

Czy formację modernistów określać by miała solidarność grupowa, właściwa reprezentantom awangardyzmu, których konstytutywne wyznaczniki zdają się odpowiadać wstępnie zarysowanej propozycji Nycza? A jeśli tak, to do jakiej formacji włączyć twórców urodzonych w latach sześćdziesiątych, Jana Kasprowicza

wiającej tematy życia codziennego (przeciwstawianej sztuce historycznej); francuski symbolizm $\mathrm{w}$ dwóch wariantach, (w wariancie stworzonym przez poezję Rimbauda oraz przez poezję Mallarmego) [zob. W. Bolecki, Modernizm w literaturze polskiej XX wieku (rekonesans), „Teksty Drugie" 2002, nr 4, s. 12-13]. Bolecki wyraźnie więc podkreśla istotę XIX-wiecznej tradycji dla rozumienia tego terminu.

32 T. Lewandowski, Język modernizmu: prolegomena historycznoliterackie, Ryszard Nycz, Wrocław 1997: [recenzja], „Pamiętnik Literacki” 1999, nr 2, s. 201.

33 Podobne niebezpieczeństwo $\mathrm{w}$ związku $\mathrm{z}$ tak szerokim rozumieniem modernizmu zauważa także Bolecki, który formułuje wnioski zbliżone do tych z cytowanej recenzji. Jego zdaniem, koncepcja tego typu: „pozwala opisywać «modernizm» (jako ogół zjawisk awangardowych) w jego długim trwaniu przez kolejne dziesięciolecia literatury polskiej XX w. Stanowisko to pozwala też wprowadzić do historii literatury polskiej kategorię postmodernizmu w znaczeniu postawangardy. Jednak taka koncepcja byłaby źródłem istotnego kłopotu. Termin «modernizm» stałby się bowiem homonimem - oznaczałby równocześnie i Młodą Polskę (w znaczeniu historycznym), i awangardę (w znaczeniu projektującym), czyli wszędzie tam, gdzie termin ten by się pojawiał, trzeba by redefiniować jego znaczenie. Po drugie - i to jest argument najważniejszy - stanowisko to oznaczałoby faktycznie uznanie paradygmatu awangardy za kryterium definiowania pojęcia «nowoczesności», czyli tak, jak rozumieli ją polscy awangardziści w okresie międzywojennym [...]. Oznaczałoby to uprzywilejowanie jednej historycznej perspektywy (literatura II Rzeczypospolitej przeciw literaturze Młodej Polski). W ten sposób poza klarowną opozycją modernizmu i awangardy pozostałaby twórczość pisarzy, którzy nie mieściliby się ani w jednym, ani w drugim paradygmacie [...]" [W. Bolecki, Modernizm w literaturze polskiej XX wieku (rekonesans), s. 16-17]. 
i Zenona Przesmyckiego, Kazimierza Przerwę-Tetmajera i Stefana Żeromskiego, Stanisława Przybyszewskiego i Władysława Stanisława Reymonta, nie uczestniczących w przemianach literackich, estetycznych i światopoglądowych następujących u progu drugiego dziesięciolecia XX wieku, tzn. we „wczesnej, założycielskiej fazie literatury nowoczesnej” (s. 40)? Nycz zdaje się skazywać pisarzy urodzonych w latach sześćdziesiątych XIX wieku na istnienie w historycznoliterackiej próżni ${ }^{34}$.

W ujęciu prezentowanym przez krakowskiego historyka literatury tytułowi bohaterowie niniejszego artykułu - Żeromski i Reymont, zostają wykluczeni z kręgu modernistycznej literatury, a ponadto - co nader zaskakujące - bardziej modernistyczny od nich paradoksalnie staje się Hłasko.

Pomimo tych spornych kwestii dotyczących rozdźwięku czasowego i - co za tym idzie - pokoleniowego wymienione w zasadniczej części artykułu podobieństwa bezspornie świadczą o tym, iż Wilk nie byłby tą samą powieścią gdyby nie młodopolskie inspiracje ukryte pod literackim kamuflażem, jaki stosuje Hłasko. Co prawda rozpoznanie pewnych motywów nie wymaga nader rozbudowanej erudycji, jednak dopiero głębsze przyjrzenie się opisom, językowym stylizacjom, a przede wszystkim funkcji muzyki pozwala w pełni odkryć, jak wiele zaczerpnął Hłasko z prozy przełomu wieków XIX i XX. Wrażliwość na piękno melodii i obrazu, liryczność opisu i przetworzenie technik pisarskich autorów młodopolskich oraz problematyka dotycząca społecznych marginesów i szybko postępujących zmian cywilizacyjnych sprawiają, że przy omawianiu Wilka nie sposób pominąć wpływu Młodej Polski. Gdyby nie zidentyfikowanie i wydanie tej powieści, obraz dorobku Hłaski byłby niepełny i zdecydowanie uboższy, dlatego o Wilku naprawdę warto mówić.

\section{Bibliografia}

Bolecki Włodzimierz (2002), Modernizm w literaturze polskiej XX wieku (rekonesans), ,Teksty Drugie" nr 4, s. 11-34.

Hejmej Andrzej (2001), Muzyczność dzieła literackiego, Wrocław: Funna.

Hłasko Marek (1989), Piękni dwudziestoletni, Warszawa: Czytelnik.

Hłasko Marek (2015), Wilk. Wydanie krytyczne, Warszawa: Wydawnictwo Iskry.

Lewandowski Tomasz (1999), Język modernizmu: prolegomena historycznoliterackie, Ryszard Nycz, Wrocław 1997: [recenzja], „Pamiętnik Literacki” nr 2, s. 198-208.

\footnotetext{
34 T. Lewandowski, Język modernizmu: prolegomena historycznoliterackie, Ryszard Nycz, Wrocław
} 1997: [recenzja], s. 200-201. 
Młynarczyk Radosław (2015), Wstęp, w: M. Hłasko, Wilk. Wydanie krytyczne, Warszawa: Wydawnictwo Iskry.

Młynarczyk Radosław (2018), Odkrył nieznanq powieść Marka Hłaski. „Niezwykły łut szczęścia”, „TVN24.pl”, https://www.tvn24.pl/xiegarnia,66,m/xiegarnia-w-tvn 24,602226.html.

Nycz Ryszard (1997), Język modernizmu. Prolegomena historycznoliterackie, Wrocław: „Leopoldinum” Wydawnictwo Fundacji dla Uniwersytetu Wrocławskiego.

Puchalska Mirosława (2008), Wokół Młodej Polski. Szkice i sylwetki, Warszawa: Instytut Badań Literackich PAN.

Pyszny Joanna (1999), Wstęp, w: M. Hłasko, Pierwszy krok w chmurach; Następny do raju, Wrocław: Zakład Narodowy im. Ossolińskich.

Reymont Władysław (1956), Nowele, t. 1, red. Z. Skrzatówna, Kraków: Wydawnictwo Literackie.

Reymont Władysław (2002), Korespondencja 1890-1925, oprac. B. Koc, Warszawa: Ludowa Spółdzielnia Wydawnicza.

Stabro Stanisław (1985), Legenda i twórczość Marka Hłaski, Wrocław: Zakład Narodowy im. Ossolińskich.

Tańczuk Renata (2015), "Pejzaż dźwiękowy” jako kategoria badań nad doświadczeniem miasta, „Audiosfera. Koncepcje - Badania - Praktyki”, nr 1, s. 10-19.

Tyrmand Leopold (2014), U brzegów jazzu, Warszawa: Wydawnictwo MG.

Wasilewski Piotr (1994), Śladami Marka Hłaski, Kraków: Oficyna Wydawnicza Parol.

Wiegandt Ewa (1980), Problem tzw. muzyczności prozy powieściowej XX w., w: Pogranicza i korespondencje sztuk. $Z$ dziejów form artystycznych w literaturze polskiej, red.

T. Cieślikowska, J. Sławiński, Wrocław: Zakład Narodowy im. Ossolińskich.

Żeromski Stefan (1982), Przedwiośnie, Wrocław: Zakład Narodowy im. Ossolińskich.

Żeromski Stefan (1997), Ludzie bezdomni, w: S. Żeromski, Pisma zebrane, t. 8, red. Z. Goliński, oprac. W. Wasilewska, Warszawa: Czytelnik.

\section{Wilk by Marek Hłasko or Young Poland Camouflaged: The Hidden Allusions to Prose Writings of Żeromski and Reymont}

Abstract

This article analyzes the novel Wilk (English "wolf"), which was written by Marek Hłasko, discovered by Radosław Młynarczyk, and then published only in 2015. The novel depicts the lives of the residents of a Warsaw district, Marymont during the interwar period. The analysis of this text by young Hłasko sheds new light on the current academic criticism of the writer's works, and shows - sometimes indirectly - his inspiration with the literary representatives of Young Poland - Stefan Żeromski and Władysław Reymont. The discovery of the literary camouflage used by the writer discloses the following components of the Young Poland period: sensitivity to the beauty of melody and image, lyrical description and the question of rapid civilization changes.

Keywords: Polish novel, literary criticism, intertextuality, Young Poland, socialist realism 